\title{
市販牛肉中に検出されたクレゾール
}

（平成元年 1 月 30 日受理）

$\begin{array}{lll}\text { 松本比佐志* } & \text { 桑原克義* } & \text { 村上保行* } \\ \text { 西宗高弘* } & \text { 末木賢二* }\end{array}$

\section{Cresol Isomers Contaminating Beef on the Market}

\author{
Hisashi Matsumoto, Katsuyoshi Kuwabara, Yasuyuki Murakami, \\ Takahiro Nishimune and Kenji Sueki
}

(Osaka Prefectural Institute of Public Health: 1-3-69, Nakamichi, Higashinari-ku, Osaka, Japan)

\begin{abstract}
An analytical procedure for three cresol isomers $(o-, p$-, and $m$-isomers) contaminating beef was developed. Isolation of the compounds from the beef was efficiently carried out by steam distillation which was followed by liquid-liquid partition of the distillate with diethyl ether. The extracts were analyzed by gas chromatography (GC) in combination with capillary GC-mass spectrometry.

The three isomers were all detected in a sample of ground beef and in hamburger containing that beef. The concentrations of $o_{-}^{-,} p$ - and $m$ - cresol in the beef were 1.7, 7.9 and 17.9 ppm, respectively. Though the concentration of each cresol isomer in the hamburger was slightly less than that in the ground beef, the ratio of each isomer in the hamburger was the same as that in the beef. The cresol isomers were not detected in five other beef samples on the market. The detection limit of each isomer was $0.2 \mathrm{ppm}$.
\end{abstract}

(Received January 30, 1989)

Key words: クレゾール異性体 cresol isomers; 牛肉 beef; ガスクロマトグラフィー (FID) gas chromatography (FID); ガスクロマトグラフィー-マススペクトロメトリー gas chromatography-mass spectrometry

\section{はじめに}

有毒な，若しくは有害な物質が含まれ，あるいは付着 する食品の販売は, 食品衛生法第 4 条において禁止され ている1). 牛肉中にクレゾールが混入することはまさに この事例に該当する*1。著者らは昭和 63 年 6 月末に試 料の分析依頼を受け，緊急に牛肉中のクレゾール分析法 を確立する必要にせまられた。

クレゾールの分析法にはガスクロマトグラフィー (GC )$^{2), 3)}$, 高速液体クロマトグラフィー (HPLC) $)^{4)}$ などがある が食肉からのクレゾール抽出並びに分離法に関する報告 はほとんど認められない, そこで, 著者らはクレゾール 化合物の物理化学的性状)を考慮し, 抽出分離の方法之 して衛生試験法注解記載の食品添加物・保存料の系統的

* 大阪府立公衆衛生研究所：大阪市東成区中道 1-3-69

*1 朝日, 読売, 毎日, 日本経済の各新聞: 昭和 63 年 7 月 12 日 朝刊.
試験法 ${ }^{6)}$ の適用を検討した，その結果，良好な分析法が得 られたので報告する.

\section{実験方法}

1. 試料

クレゾール混入の疑いのある牛ミンチ肉 1 検体及び その肉を用いたハンバーグ 1 検体と昭和 63 年 $7 \sim 8$ 月 に購入した市販の牛肉 5 検体を用いた。

\section{2. 試薬}

ジェチルエーテル，エタノール，アセトニトリル及び 無水硫酸ナトリウムは和光純薬工業(株)製, 残留農薬分 析用のものを用いた。 $o-p$ - 及び $m$-クレン゙ールは東京化 成工業(株)製, 特級品のあの, 塩化ナトリウム, 酒石酸 及び塩酸は和光純薬工業(株)製, 特級品のむのを使用し た。

\section{3. 装置}

GC：島津製作所(株)製 GC-7AG 及び GC-16A, Hew- 
Table 1. Recovery of Cresol Isomers from Beef

\begin{tabular}{cccc}
\hline \hline \multirow{2}{*}{ Added $(\mu \mathrm{g})$} & \multicolumn{3}{c}{ Recovery (\%) } \\
\cline { 2 - 4 } & $o$-Cresol & $p$-Cresol & $m$-Cresol \\
\hline 20 & 85 & 95 & 98 \\
100 & 83 & 87 & 91 \\
\hline
\end{tabular}

Values were means of two determinations. The three cresol isomers (20 or $100 \mu$ g portions) were mixed with fifty grams of beef purchased from the market.

lett Packard 社製, 5710A 型（マススペクトロメトリー (MS) と連結)

MS：日本電子(株)製 JMA DX-300

データ分析システム：日本電子(株)製 JMA 3500 (MS と連結)

\section{GC 条 件}

Gas chrom Q (80/100 mesh, Applied Science 社製) に変性ラノリン $(10 \%)$ をコーテングしたものをガラス カラム（内径 $3 \mathrm{~mm}$, 長さ $2.0 \mathrm{~m}$ ) につめ, これを分離用 カラムとして使用しだ). カラム温度は $160^{\circ}$, 注入口及 び検出器温度は $200^{\circ}$ とた。 キャリヤーガスは $\mathrm{N}_{2}$ を用 い, 流量を $40 \mathrm{ml} / \mathrm{min}$ とした. GC は FID モードで使用 した.

\section{5. キャピラリー GC/MS 条件}

クレゾールの分離及び定性を行うため，キャピラリー カラム (CURABOND-WAX, 内径 $0.32 \mathrm{~mm}$, 長さ 30 $\mathrm{m}$, 膜厚 $0.25 \mu \mathrm{m}, \mathrm{J} \& \mathrm{~W}$ 社製）を用い, $70^{\circ}$ （2 分間定

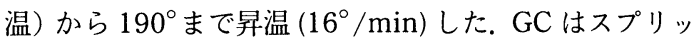
トレス方式で使用した. キャリヤーガスは $\mathrm{He}$, 流速は 1 $\mathrm{ml} / \mathrm{min}$ に調整した. MS は，イオン化電圧 $70 \mathrm{eV}, \mathrm{EI}$ モードで測定した.

\section{6. 試験溶液の調製}

衛生試験法注解の食品添加物 - 保存料の系統的試験

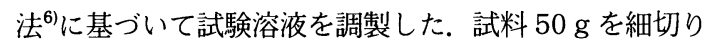
にし，これに蒸留水 $100 \mathrm{ml}$, 塩化ナトリウム $80 \mathrm{~g}$ 及び $15 \%$ 酒石酸溶液 $5 \mathrm{ml}$ を加え, 水蒸気蒸留を行った. 留 液 $200 \mathrm{ml}$ (所要時間は約 20 分間）を取り，これに塩化 ナトリウム $50 \mathrm{~g}, 10 \%$ 塩酸 $5 \mathrm{ml}$ 及びジェチルエーテル $50 \mathrm{ml}$ を加え, $500 \mathrm{ml}$ 容の褐色分液漏斗中で振とう抽 出を行った， 1 時間放置した後，この水層を取り，これ にジェチルェーテル $50 \mathrm{ml}$ を加え, 更に振とう分離を行 った。この操作を再度繰り返した（合計 3 回抽出）後, ジェチルェーテル抽出液を合わせた. これに無水硫酸ナ トリウムを加えて脱水した後, ガラス漏斗 $11 \mathrm{G} 1$ を用い てろ過した。 ろ液にエタノール $2 \mathrm{ml}$ を加え，これを試 験管付きポット（クーデルナ・ダニッシュ濃縮装置の一 部)に入れた後, 湯浴 ( $80^{\circ}$ 以下) 中に浸してェーテルを 留去した. 溶媒が試験管に残った状態 (約 $5 \mathrm{ml}$ ) で留去

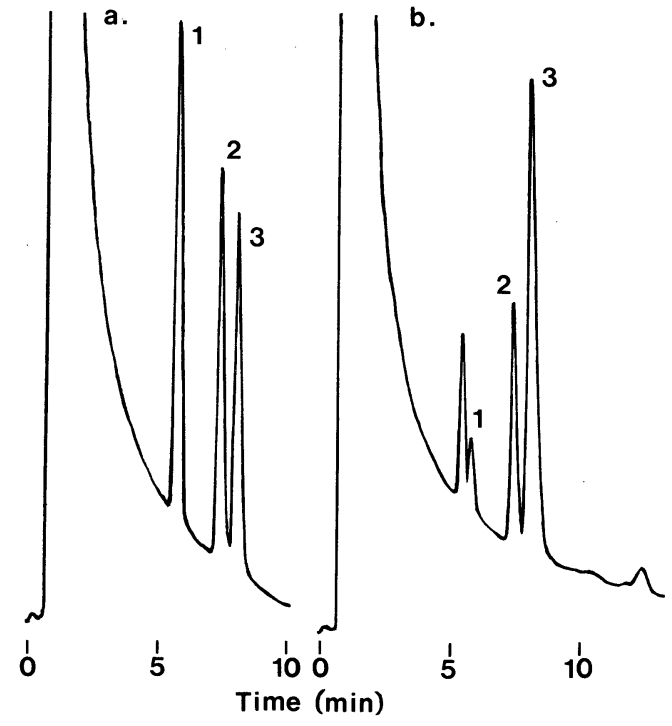

Fig. 1. Gas chromatograms of cresol isomers and the ground beef extract

a: cresol isomers (each $0.3 \mu \mathrm{g}$ )

b: ground beef extract (adjusted to 10 $\mathrm{ml})$

1: $o$-cresol; 2 : $p$-cresol; $3: m$-cresol

GC conditions: column, $10 \%$ denatured lanoline/Gas chrom Q (3 mm i.d. $\times 2.0 \mathrm{~m})$; column temp., $160^{\circ} \mathrm{C}$; injection temp., $200^{\circ} \mathrm{C}$; carrier gas, $\mathrm{N}_{2}(40 \mathrm{ml} / \mathrm{min})$

を止め, 次に窒素気流を吹きつけて溶媒を除去し, 最終 容量 $2 \mathrm{ml}$ に調製した.この溶液の $5 \mu \mathrm{l}$ （キャピラリー GCの場合は $2 \mu \mathrm{l})$ を GCに注入した。

\section{結果及び考察}

GC による $o-, p$ - 及び $m$-クレゾールの検量線は, 各々 50 から $500 \mathrm{ng}$ まで直線となることが分かった. そこで 先ず, クレゾールの濃縮時における揮散の有無を調べる ため, 各々 $100 \mu \mathrm{g}$ のクレン゙ール化合物をジェチルェー テル $150 \mathrm{ml}$ と混ぜた後, これを試験溶液の調製の項と 同様の方法で濃縮したところ, 各種クレゾールの回収率 は $100 \%$ に近いことが分かった. 次に, 水蒸気蒸留によ る最適留液量を決めるため, クレゾールが混入していな いことをあらかじめ確かめた市販牛肉 $50 \mathrm{~g}$ に各々 500 $\mu \mathrm{g}$ のクレゾール化合物を添加した後, 試験溶液の調製 の項に従って水蒸気蒸留を行い, 一定留液ごとにクレン゙ ール量を測定した. $o$-, $p$ - 及び $m$-体は留液 $100 \mathrm{ml}$ まで に各々 81,82 及び $85 \%$ の留出が認められた. 引き続き 留液 $50 \mathrm{ml}$ ずつ $250 \mathrm{ml}$ までの留出量を調べたところ, $o$-体: $6.5,2.7,1.6, p$-体: 7.8, 3.4, 2.0 及び $m$-体: 8.3, 3.6, $2.2 \%$ の回収率となり, 順次その留出量は減少した。 各 種クレゾールを $90 \%$ 以上回収するためには留液を 200 
Table 2. Concentration of Cresol Isomers in the Ground Beef, Hamburger Containing that Beef, and Other Beef Samples on the Market

\begin{tabular}{lccc}
\hline \hline & \multicolumn{3}{c}{ Concentration $(\mathrm{ppm})$} \\
\cline { 2 - 4 } & $o$-Cresol & $p$-Cresol & $m$-Cresol \\
\hline Ground beef & $1.6, \quad 1.8$ & $7.3,8.5$ & $16.8, \quad 18.9$ \\
Hamburger & 1.2 & 6.4 & 14.0 \\
Beef on the market $(n=5)$ & all ND* & all ND* & all ND* \\
\hline
\end{tabular}

* ND: not detected (detection limit: 0.2 ppm).

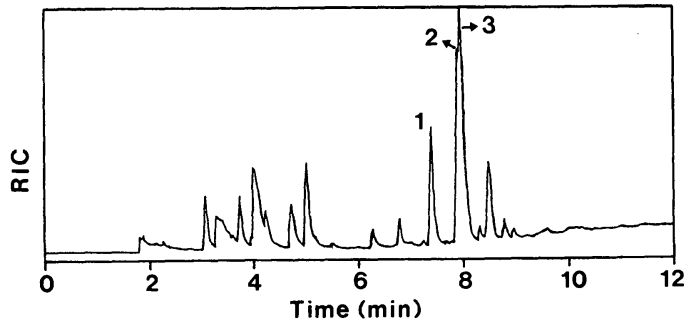

Fig. 2. Reconstructed ion chromatogram of $\mathrm{GC} / \mathrm{MS}$ analysis of the ground beef extract

1: $o$-cresol; 2: $p$-cresol, 3: $m$-cresol

GC conditions: column, DURABONDWAX $(0.32 \mathrm{~mm}$ i.d. $\times 30 \mathrm{~m}$, film thickness $0.25 \mu \mathrm{m})$; column temp., $70^{\circ} \mathrm{C}(2 \mathrm{~min}) \rightarrow$ $\left(16^{\circ} \mathrm{C} / \mathrm{min}\right) \rightarrow 190^{\circ} \mathrm{C}$; carrier gas, $\mathrm{He}(1 \mathrm{ml} /$ min); splitless mode

MS conditions: ionization voltage, 70 eV; El mode

$\mathrm{ml}$ 採取すればよいことが分かった。

市販牛肉に各種クレゾールを添加したときの回収率を Table 1 に示す. 各々 $20 \mu \mathrm{g}$ のクレゾール化合物を添加 したときの回収率は 85〜98\% であり, $100 \mu \mathrm{g}$ 添加群で は 83〜91\% となりほぼ良好な結果を得た。なお, 検出 限界は $0.2 \mathrm{ppm}$ であった。

Fig. 1 に各種クレゾールの標準品及び牛ミンチ肉の抽 出液のクロマトグラムを示す。標準品の保持時間と牛ミ ンチ肉試料のそれとの比較から,この試料中に各種クレ ゾールが確認できた. Table 2 には, 牛ミンチ肉, 食べさ しのハンバーグ及び市販牛肉の分析結果を示す。牛ミン 千肉と同様にハンバーグにも各種クレゾールが検出され た. 各種クレゾールの混合比は牛ミンチ肉及びハンバー グにおいてほとんど変わらない值を示した（o-体:p-体： $m$-体 $=6: 29: 65$ (牛ミンチ肉中)； $6: 30: 65$ (ハンバー グ中)). 又, この牛ミンチ肉を冷凍庫 $\left(-20^{\circ}\right)$ に 3 か月 間保存した後，再度分析したところ，その值はほとんど 変わらなかった。一方, 市販牛肉 5 検体はすべて検出限 界 $(0.2 \mathrm{ppm})$ 以下であった。

Fig. 2, 3 には, GC/MS による牛ミンチ肉試料中のク

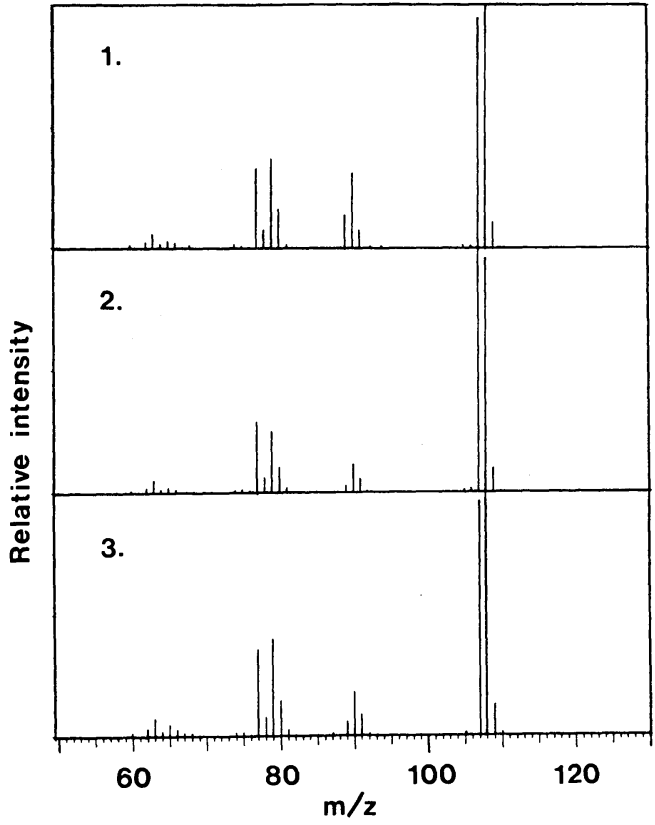

Fig. 3. Mass spectra of cresol isomers in the ground beef extract

1: $o$-cresol; 2: $p$-cresol; 3: $m$-cresol

$\mathrm{GC} / \mathrm{MS}$ conditions were the same as those in Fig. 2.

レゾール分析結果を示す。試料の Reconstructed ion chromatogram (Fig. 2) から $p$ - 及び $m$-体の分離は不十 分であるが, この二つの化合物相互の保持時間がわずか に違うことが認められた。 各種クレゾール標準品のマス スペクトルは，Heller ら7によるそれと同様のフラグメ ントパターンを示すことが分かった． $o-, m$-体では親イ オン $(m / z 108)$ の相対イオン強度が最も高いが, $p$-体で は $m / z 107\left(\mathrm{M}^{+}-1\right)$ のイオンが最大の強度を示した。 更に, $o$-体では $m / z 77$ 及び 79 の相対イオン強度と $m /$ $z 90$ によるそれとはほぼ同程度の值を示したが, $p$-及び $m$-体では $m / z 77$ 及び 79 に比べ $m / z 90$ のイオン強度 が低いことが分かった。このことは各種標準品と同一の 保持時間に当たる牛ミンチ肉試料中のそれぞれの化合物 
についても全く同様の結果となった (Fig. 3).

以上述べてきたことから，今回の実験結果は明らかに 牛ミンチ肉に各種クレゾールが混入していたことを示し ている，と畜場においては病死牛肉を識別するためにク レゾールを散布することもあるといわれている。また， これらの牛肉は主にペットフードとして使用されること から，この牛肉が何らかの形で市場に出回った可能性が 考えられる*2. クレゾールは国の毒物及び劇物取締法に 指定された劇物であり ${ }^{8)}$, ラットの経口投与による $\mathrm{LD}_{50}$ 値は各異性体で異なっており，121〜242 mg/ $\mathrm{kg}$ と報 告されている9 . 又, ヒトに対する攝取致死量は大人で 1 〜 $10 \mathrm{~g}$ といわれている*1,5). 今回のハンバーグ 1 個を子 供が食べたとしても，クレゾールの総攖取量は $1 \mathrm{mg}$ 以 下に過ぎず，大きな影響はないと考えられる。

\section{謝辞}

試料の採取に御尽力いただきました大阪府環境保健部 食品衛生課, 並びに大阪府吹田保健所の皆様方に, また 分析手法などにおきまして種々御助言をたまわりました 当所食品化学課及び環境衛生課諸氏に深謝いたします.

文献

1）厚生省生活衛生局食品保健課 - 乳肉衛生課 - 食品衛生課 編：食品衛生小六法, 昭和 60 年版, p. 2 3(1985) 新日本
法規出版.

2) Zweig, G., Sherma, J.: "Handbook of Chromatography" Vol. 1, p. 89 91, 93 (1972), CRC Press, Cleveland, Ohio.

3）厚生省生活衛生局食品保健課 - 乳肉衛生課 - 食品化学課 編：食品衛生小六法，昭和 60 年版，p. 709 711 (1985) 新日本法規出版.

4）液体クロマトグラフ研究会デー夕集績委員会編：“高速液 体クロマトグラフィーデータ集”2, Data Sheet No. 277, 278, 280, 281 (1980) アイピーシー(株).

5) Windholz, M., ed.: “The Merck Index ninth edition" p. 2,573 (1976) Merck \& Co., Inc., Rahway, N. J.

6）日本薬学会編：“衛生試験法注解” p. 298 304 (1980), 金 原出版.

7) Heller, S. R., Milne, G. W. A.: "EPA/NIH Mass Spectral Data Base" Supplement I , p. 4,021 (1980), National Bureau of Standards, Washington, D. C.

8）武田正三：“わかりやすい毒物・劇物取締法，毒物劇物関 係法令集” p. 21 (1985)，薬業時報社.

9) Lewis, R. L., Sweet, D. V., ed.: "Registry of Toxic Effects of Chemical Substances 1983 84 Supplement" Vol. 1, p. 679 680 (1985), National Institute for Ocupational Safty and Health, Cincinati, Ohio.

*2 朝日, 読売新聞: 昭和 63 年 9 月 13 日朝刊. 